\title{
Effect of feeding strategies and cropping systems on greenhouse gas emission from Wisconsin certified organic dairy farms
}

\author{
D. Liang, ${ }^{*}$ F. Sun, ${ }^{*}$ M. A. Wattiaux, ${ }^{*}$ V. E. Cabrera, ${ }^{* 1}$ J. L. Hedtcke, $†$ and E. M. Silvał \\ ${ }^{*}$ Department of Dairy Science, University of Wisconsin-Madison, Madison 53705 \\ †West Madison Agricultural Research Station, University of Wisconsin-Madison, Verona 53593 \\ łDepartment of Plant Pathology, University of Wisconsin-Madison, Madison 53705
}

\begin{abstract}
Organic agriculture continues to expand in the United States, both in total hectares and market share. However, management practices used by dairy organic producers, and their resulting environmental impacts, vary across farms. This study used a partial life cycle assessment approach to estimate the effect of different feeding strategies and associated crop production on greenhouse gas emissions (GHG) from Wisconsin certified organic dairy farms. Field and livestock-driven emissions were calculated using 2 data sets. One was a 20-yr data set from the Wisconsin Integrated Cropping System Trial documenting management inputs, crop and pasture yields, and soil characteristics, used to estimate field-level emissions from land associated with feed production (row crop and pasture), including $\mathrm{N}_{2} \mathrm{O}$ and soil carbon sequestration. The other was a data set summarizing organic farm management in Wisconsin, which was used to estimate replacement heifer emission ( $\mathrm{CO}_{2}$ equivalents), enteric methane $\left(\mathrm{CH}_{4}\right)$, and manure management $\left(\mathrm{N}_{2} \mathrm{O}\right.$ and $\left.\mathrm{CH}_{4}\right)$. Three combinations of corn grain (CG) and soybean (SB) as concentrate (all corn $=100 \% \mathrm{CG}$; baseline $=75 \% \mathrm{CG}+25 \%$ $\mathrm{SB}$; half corn $=50 \% \mathrm{CG}+50 \% \mathrm{SB}$ ) were assigned to each of 4 representative management strategies as determined by survey data. Overall, GHG emissions associated with crop production was 1,297 $\pm 136 \mathrm{~kg}$ of $\mathrm{CO}_{2}$ equivalents/t of ECM without accounting for soil carbon changes $(\triangle \mathrm{SC})$, and GHG emission with $\Delta \mathrm{SC}$ was $1,457 \pm 111 \mathrm{~kg}$ of $\mathrm{CO}_{2}$ equivalents/t of ECM, with greater reliance on pasture resulting in less $\Delta \mathrm{SC}$. Higher levels of milk production were a major driver associated with reduction in GHG emission per metric tonne of ECM. Emissions per metric tonne of ECM increased with increasing proportion of SB in the ration; however, including SB in the crop rotation decreased
\end{abstract}

Received August 23, 2016.

Accepted March 27, 2017.

${ }^{1}$ Corresponding author: vcabrera@wisc.edu
$\mathrm{N}_{2} \mathrm{O}$ emission per metric tonne of ECM from cropland due to lower applications of organically approved $\mathrm{N}$ fertility inputs. More SB at the expense of $\mathrm{CG}$ in the ration reduced enteric $\mathrm{CH}_{4}$ emission per metric tonne of ECM (because of greater dietary fat content) but increased $\mathrm{N}_{2} \mathrm{O}$ emission per metric tonne of ECM from manure (because of greater $\mathrm{N}$ content). An increased reliance on pasture for feed at the expense of grain resulted in decreased in milk production, subsequently leading to substantially higher emissions per metric tonne of ECM.

Key words: partial life cycle assessment, carbon footprint, grazing management

\section{INTRODUCTION}

The market for organic products continues to expand both in the United States and abroad, reaching approximately $\$ 35$ billion sales in 2014 (USDA Economic Research Service, 2013). Organic milk demand has recently surpassed available supply, unable to keep pace with consumer demand (McBride and Greene, 2009). As new farms transition to organic production to meet the rising demand for organic milk, farmers likely will need to adjust the feeding strategies used for their conventional herds to achieve the required minimum of $30 \%$ DMI from pasture during the grazing season, as outlined by the USDA National Organic Program (USDA, 2013). Within this regulatory framework, however, different approaches relating to both crop production strategy and feed ration composition exist that could be adopted by organic dairy farmers. Wisconsin's organic dairy farms currently exhibit a wide range of these approaches, including varying reliance on pasture or concentrates (Hardie et al., 2014); these farms could serve as models for transitioning producers aspiring to attain specific production, economic, and environmental benchmarks under organic management.

Across all of agriculture, increasing attention has been focused on greenhouse gas (GHG) emissions resulting from production practices and their associated effects 
on climate change (IPCC, 2013). Agriculture contributes approximately $9 \%$ to total GHG emissions in the United States and 14\% of emissions globally (EPA, 2014). Whereas the dairy industry is not a particularly significant source of total global anthropogenic GHG emissions (4\% in 2010), the US dairy industry has committed to a $25 \%$ reduction of GHG by 2020 relative to 2009 (Innovation Center for US Dairy; http://www. usdairy.com/sustainability/industry-commitment/ about). The major sources and sinks of GHG on the dairy farm are associated with crop production $\left(\mathrm{CO}_{2}\right.$ and $\mathrm{N}_{2} \mathrm{O}$ ), enteric fermentation of feed by livestock $\left(\mathrm{CH}_{4}\right)$, and manure management $\left(\mathrm{CH}_{4}\right.$ and $\left.\mathrm{N}_{2} \mathrm{O}\right)$. Variations in diet formulation, and the associated crop production to supply that diet, can affect the quantity of GHG emissions of the various systems, as highlighted by several studies demonstrating the importance of feed quantity and quality to reduce livestock GHG emission intensity (Johnson and Johnson, 2007; Ogino et al., 2007; Beauchemin et al., 2010; Pelletier et al., 2010).

Life cycle assessment (LCA) has been used to evaluate the GHG emissions from dairy operations on a whole-farm level. Studies have compared GHG emissions of confinement-based feeding operations to pasture-based systems, including organically managed systems that include pasture (Cederberg and Mattsson, 2000; Weiske et al., 2006). Several studies indicated that the amount of concentrate fed to dairy herds, and its associated crop production-based GHG emissions and subsequent effects on feed digestibility, enteric methane emissions, and milk productivity (Aguerre et al., 2011; Beauchemin et al., 2008).

As farms make the transition to certified organic practices, critical decisions must be made with respect to feeding strategies and diet composition. Thus, with increasing numbers of dairy operations under organic management, the optimization of feeding strategies provides an opportunity to minimize the carbon footprint of organic dairy farms in Wisconsin while maintaining productivity. Therefore, the objective of our study was to compare the effects of potential feeding strategies and the associated crop hectares on GHG emissions of Wisconsin certified organic dairy farms.

\section{MATERIALS AND METHODS}

\section{Feeding Strategies}

An analysis from a 2010 survey of Wisconsin certified organic dairy farm management characteristics (Hardie et al., 2014) revealed 4 feeding strategies and production outputs typifying Wisconsin organic dairy farms. Farms were clustered using 9 parameters under 3 general categories: (1) general farm characteristics and management (herd size, percent of Holstein cows, and milking frequency); (2) nonpasture-based feeding practices (number of cow groups, amount of concentrate fed, and feed supplements); and (3) grazing practices (percent of land used as pasture, pasture occupancy period, and grazing season length). Detailed descriptions of herd and management factors for the farms in each of the clusters (number of cows, rolling herd milk average, percent Holstein cows, concentrate fed, land used as pasture, length of grazing season, and average hours per day on pasture) are summarized in Table 1 (Hardie et al., 2014). Greenhouse gas emission allocation between milk and meat was calculated for each cluster, which was based on the weight of meat (bull calf and beef sale) and milk sale (IDF, 2010). Results reported as GHG emission per metric tonne of ECM represented the GHG emission allocated to $1 \mathrm{t}$ of ECM, with exceptions noted in the table footnotes, in which $\mathrm{N}_{2} \mathrm{O}$ and $\mathrm{CH}_{4}$ emission from each emission source and soil carbon loss value were total emission for both milk and meat.

Cluster 1 comprised 8 farms with an average herd size of 128 cows. The predominate breed in cluster 1 was Holstein, with lesser represented breeds including Jersey, Milking Shorthorn, Brown Swiss, Swedish Red, Normande, Dutch Belted, Linebacks, and Fleckvieh (Hardie, 2013). The lactating cows of the farms described by this cluster heavily relied on supplementation and minimally on pasture. Cow management was the most similar to conventional management strategies among all 4 clusters; it had the least hours per day on pasture compared with the other 3 clusters, low percentage of land designated to pasture, high levels of concentrate feeding, and high DMI. The productivity per cow (i.e., ECM) was second-highest among the clusters.

Cluster 2 comprised 5 farms with an average of 50 cows each of varying breeds (both purebred and crossbred of Jersey, Milk Shorthorn, Normande, Brown Swiss, Ayrshire, and New Zealand Friesian; only 1 farm had 12\% purebred Holsteins; Hardie, 2013) that used seasonal calving. Farms in cluster 2 grazed more days annually than other clusters, had the greatest percent of land under pasture, and used the least amount of concentrate. In part due to seasonal milking, the productivity of these herds was the lowest of all clusters.

Cluster 3 comprised 32 farms with an average herd size of 41 cows. Similar strategies were used as in cluster 1 for feeding their smaller herds, feeding $6 \mathrm{~kg} / \mathrm{d}$ of concentrate per cow. Cluster 3 was $89 \%$ purebred Holstein; other purebred cows were Jersey and Lineback breeds. The crossbred cows had the genetics of Holstein, Jer- 
sey, Milking Shorthorn, Brown Swiss, Angus, Guernsey, Swedish Red, Normande, Dutch Belted, Montbéliarde, Lineback, Danish Red, Friesian, or Norwegian Red (Hardie, 2013). Average hours on pasture per day for cows were greater than cluster 1 . Although percentage of time grazing pasture was similar, the percentage of land designated as pasture in cluster 3 was substantially greater than the farms of cluster 1 . The highest rolling herd average milk production was found on the farms of this cluster.

Cluster 4 comprised 24 farms with an average herd size of 43 cows, typically not-milking purebred Holstein. Crossbreds in cluster 4 had similar genetics as cluster 3 (Hardie, 2013). Cows of cluster 4 farms spent more time on pasture during the grazing season, with more land designated to pasture than clusters 1 and 3. During the nongrazing season, lactating cow feeding strategies were similar to clusters 1 and 3. Milk production was less than that of farms from clusters 1 and 3 .

\section{Cropland and Pasture GHG Emissions}

The Wisconsin Integrated Cropping Systems Trial (WICST), a long-term cropping system experiment established in 1989 and located in Arlington, Wisconsin, has been used to collect crop production and soil data from 0.28 -ha plots managed to represent production practices representative of Wisconsin agriculture (Posner et al., 1995, 2008; Sanford et al., 2012). The various cropping systems studied in the WICST trial include both organic grain-based and forage-based systems that are managed according to the USDA National Organic Program regulations (USDA, 2013) and represent cash grain (corn-soybean-wheat rotation) and forage production strategies (corn-oat/alfalfa-alfalfa rotation) used among Wisconsin's organic dairy farmers (Posner et al., 2008). Inputs (seed, fertilizer and nutrients pesticides, and so on) as well as crop and pasture yield measurements are collected annually, with each phase of the crop rotation represented each year, providing a robust estimate of the yield potential on organically managed crop land in southern Wisconsin. Using the average yield data from a 16-yr period (1993-2008), the hectares required to produce the annual feed needs per cow for each of the model feeding strategies [corn grain (CG) and soybean (SB)] in concentrate, silage, alfalfa haylage, and pasture were estimated for each cluster. These values were calculated according to the annual DM consumption of the lactating herd, annual crop yields, and feed moisture content using the reported values of each cluster was daily feed consumption from Hardie et al. (2014).

Emissions of $\mathrm{N}_{2} \mathrm{O}$ and $\mathrm{CH}_{4}$ from cropland and pasture were predicted based on input and yield data from the 16-yr (1993 to 2008) period on which this information was collected from the organic grain and forage rotations and pasture treatments on WICST. Using IPCC (2006b) equations, direct $\mathrm{N}_{2} \mathrm{O}$ emissions from crop production and indirect $\mathrm{N}_{2} \mathrm{O}$ emissions from leaching and volatilization were calculated. Emissions were

Table 1. Descriptive statistical results of 4 clusters $^{1}$ and the total sampling farms from Hardie et al. $(2014)^{2}$

\begin{tabular}{|c|c|c|c|c|}
\hline Item & $\mathrm{C} 1$ & $\mathrm{C} 2$ & C3 & $\mathrm{C} 4$ \\
\hline Number of farms & 8 & 5 & 32 & 24 \\
\hline Number of cows per farm & 129 & 50 & 41 & 43 \\
\hline Rolling herd average milk production (kg/cow per year) & 6,878 & 3,632 & 7,457 & 5,417 \\
\hline $\mathrm{ECM}_{\text {production }}^{3}(\mathrm{~kg} / \mathrm{cow}$ per year $)$ & 6,657 & 3,857 & 7,164 & 5,495 \\
\hline Percent of purebred Holstein cows & 90 & 0 & 89 & 6 \\
\hline Percent of first lactation cows & 31.6 & 32.7 & 29.7 & 26.1 \\
\hline Number of bull calves sold per year & 39 & 19 & 15 & 16 \\
\hline Concentrate fed per cow per day $(\mathrm{kg} / \mathrm{d})$ & 8.0 & 2.0 & 6.0 & 6.0 \\
\hline DMI ( $\mathrm{kg} / \mathrm{cow}$ per day) & 22.1 & 15.2 & 20.9 & 18.1 \\
\hline Percent of land used as pasture & 22 & 100 & 31 & 49 \\
\hline Grazing period starting and ending time & Apr. 19-Nov. 7 & Apr. 26-Nov. 28 & May 1-Oct. 21 & Apr. 21-Nov. 8 \\
\hline Grazing period length (d) & 203 & 216 & 176 & 199 \\
\hline Average hours per day on pasture during grazing season & 17 & 22 & 19 & 21 \\
\hline Grazing time on pasture ${ }^{4}(\mathrm{~d} / \mathrm{yr})$ & 143 & 194 & 141 & 174 \\
\hline Allocation factor to milk ${ }^{5}$ & 0.82 & 0.71 & 0.85 & 0.84 \\
\hline
\end{tabular}

${ }^{1}$ Cluster $1=\mathrm{C} 1$; cluster $2=\mathrm{C} 2$; cluster $3=\mathrm{C} 3$; and cluster $4=\mathrm{C} 4$.

${ }^{2}$ Energy-corrected milk production, feed efficiency, and grazing time on pasture in a year were calculated based on data from Hardie et al. (2014). Other results were calculated based on survey results from Hardie (2013).

${ }^{3} \mathrm{ECM}=[0.25+0.122 \times$ fat $(\%)+0.077 \times$ protein $(\%)] \times$ milk production $(\mathrm{kg})($ Sjaunja et al., 1990$)$.

${ }^{4}$ Grazing time on pasture in a year is the actual time $(\mathrm{d})$ cows graze on pasture during 1 -yr period, calculated as grazing period length $\times($ average hours per day on pasture during grazing season/24).

${ }^{5}$ Allocation factor to milk is the proportion of total GHG emission allocated to milk. It is calculated as $1-5.7717 \times\left(\mathrm{M}_{\text {meat }} / \mathrm{M}_{\text {milk }}\right)$, where $\mathrm{M}_{\text {meat }}$ is the amount of meat sale per year, including culled cows and bull calves, and $\mathrm{M}_{\text {milk }}$ is the amount of milk sale per year (IDF, 2010). 
converted to $\mathrm{CO}_{2}$ equivalent $\left(\mathbf{C O}_{2}\right.$ eq. $)$ with global warming potential values of 298 for $\mathrm{N}_{2} \mathrm{O}$ and 34 for $\mathrm{CH}_{4}$ (100-yr time horizon with climate-carbon feedbacks; Myhre et al., 2013).

Changes in soil carbon quantities resulting from the crop management strategies represented in the WICST trial were calculated by comparing soil carbon concentrations in samples collected at the start of the trial started (in 1989) to samples collected 20 yr later (Sanford et al., 2012). Whereas this timeframe is relatively short, previous studies have demonstrated that soil carbon changes resulting from crop production activities can be accurately measured over this timespan (Bellamy et al., 2005; Milesi Delaye et al., 2013). Protocols for determining soil carbon changes and associated data were detailed in Sanford et al. (2012). For the purposes of this analysis, annual soil carbon change $(\boldsymbol{\Delta} \mathbf{S C})$ was calculated as the average annual soil change over the 20-yr period (1989-2008) assuming a linear trend.

\section{Enteric Methane Estimation}

The DMI of lactating cows in each of the 4 clusters was collected as farmer-reported data and summarized by Hardie et al. (2014). As part of Hardie et al. (2014) survey, farmers were asked to provide the DM amount of each feed type (concentrate, corn silage, alfalfa haylage, vitamin, and mineral) fed to cows in both the nongrazing and grazing seasons. The DMI consumed from pasture were calculated as the difference between the estimated total DMI (provided by the surveyed farmers) and DM consumed from supplemented feed during the grazing season. Dry matter intake from different feeding strategies for each cluster were summarized in Table 2 from Hardie et al. (2014). Three concentrates scenarios were also listed in Table 2, which is described in the Concentrate Scenarios section.

Enteric $\mathrm{CH}_{4}$ emissions are affected by multiple factors, including DMI, NDF, fat, and energy content in the diet (Johnson and Johnson, 1995). In most cases, the IPCC (2006a) equation was used for enteric $\mathrm{CH}_{4}$ emission calculation; however, a model from Moraes et al. (2014; Appendix Table A1) was used to predict $\mathrm{CH}_{4}$ emissions from enteric fermentation to better capture the variation of diet formulation [gross energy (GE) intake, dietary NDF, and dietary ether extract] in studied clusters. Additionally, the Moraes et al. (2014) model was used as the equation from IPCC (2006a) would require several parameters (i.e., daily BW gain) that were not reported in the original survey.

Feed ingredient chemical composition (Appendix Table A2) was collected from Nutrient Requirements of Dairy Cattle (NRC, 2001); GE was further calculated based on the carbohydrate, protein, and ether extract

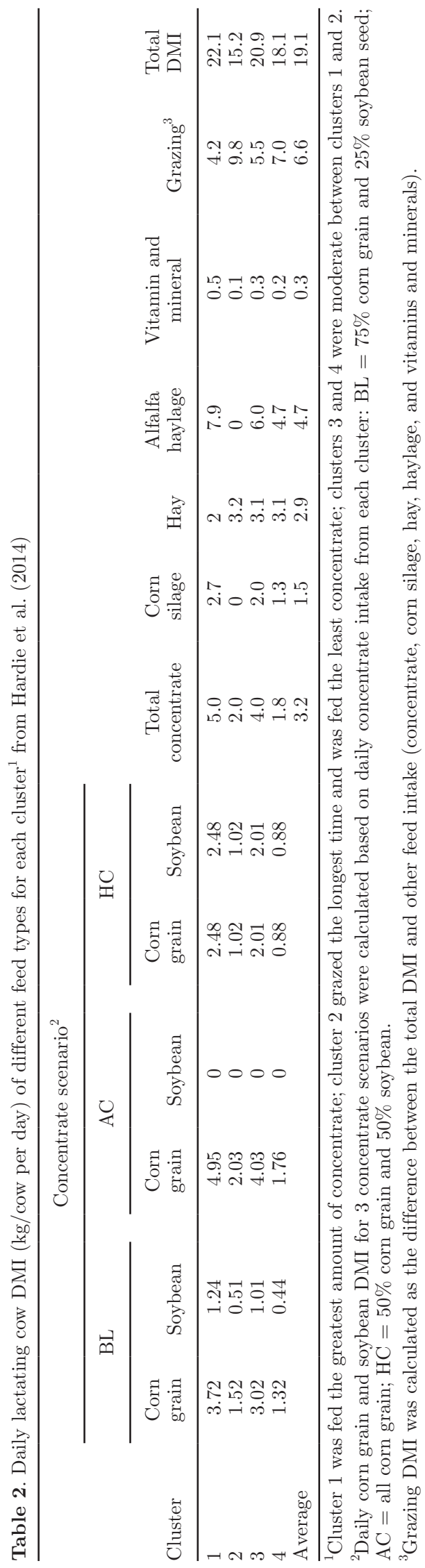


proportion. High CP contents (19-24\% in different clusters; Table 3) were due to the high DMI from pasture (Wales et al., 1998), which had relatively greater $\mathrm{CP}$ content than the other feed ingredients (Appendix Table A2). Body weight of cows and milk fat were obtained from the survey results (Hardie, 2013).

\section{Manure Management GHG Emissions}

Estimations of GHG emissions associated with manure management included manure deposited on pasture during grazing, manure storage, and manure applied to the field through mechanical spreading. Manure $\mathrm{N}$ excretion was calculated as the difference between dietary $\mathrm{N}$ and milk $\mathrm{N}$. The proportion of manure $\mathrm{N}$ deposited on pasture was determined by the annual length of the grazing season, hours in a day on pasture during the grazing period, and the monthly DMI from pasture during the grazing season; all 3 parameters were obtained from the survey of Hardie (2013; Table 1). For example, cows from cluster 1 spent $16.9 \mathrm{~h}$ (70.4\% of 24 h) on pasture during the grazing period that started on April 19 and ended on November 7; thus, 70.4\% of the manure during grazing period was deposited on pasture, with the remaining proportion collected from confinement housing. Deposited manure N content and volatile solid content were determined by the monthly DMI of each feed ingredient for each grazing month (April to November). The survey results (Hardie et al., 2014) indicated that most of the organic farms handled lactating cow manure in liquid form. Eleven farms handled only solid manure (16\%) from lactating cows: clusters 1 and 2 all handled liquid manure, cluster 3 had 8 farms (25\%) that handled solid manure, and cluster 4 had 3 farms (12.5\%) that handled solid manure. As such, it was assumed that all farms only handle liquid manure. Forty-six farms reported the storage time of liquid manure in earthen basin, 35 of them had storage time longer than 6 mo. Thus, we assumed that manure collected in confinement housing was stored in an earthen basin for 6 mo, followed by applying to crop and pasture land. Emissions of $\mathrm{CH}_{4}$ and $\mathrm{N}_{2} \mathrm{O}$ from manure management were estimated with IPCC (2006a) equations listed in Appendix Table A1.

\section{Replacement Heifer Emission}

Greenhouse gas emission from heifers was based on percent of first-lactation cows, herd size, and $\mathrm{BW}$ (Table 1). Heifer BW is $92 \%$ of mature cow BW (NRC 2001). An emission factor of $11 \mathrm{~kg}$ of $\mathrm{CO}_{2}$ eq. $/ \mathrm{kg}$ of BW (Rotz et al., 2013) was assigned to replacement heifers. Calculation is listed in Appendix Table A1. Greenhouse gas emission per heifer was 6,172, 5,541, 
5,992 , and $5,385 \mathrm{~kg}$ of $\mathrm{CO}_{2}$ eq. for clusters $1,2,3$, and 4 , respectively.

\section{Concentrate Scenarios}

To estimate the effect of diversification of feed supplementation strategies, 3 combinations of CG and SB were designed to evaluate the plausible respective GHG emissions of feeding concentrate of varying ingredient composition. These combinations (CG:SB) were (1) 100:0 (all corn; AC), (2) 75:25 (baseline; BL), and (3) 50:50 (half corn; HC). All the concentrate combination scenarios on each cluster are represented in Table 2 . Chemical composition of each concentrate scenario is depicted in Table 3, including CP, NDF, ADF, NFC, ash, and GE. Crop land needed to produce the necessary amount of grain for each diet was modified as appropriate for the different diets. The BL was used as the base scenario for comparison. Dry matter intake in each cluster fulfilled the cow's nutrient requirement (Hardie et al., 2014); the diet ration in each cluster and concentration scenario also fulfilled the cow's protein and energy requirements according to NRC (2001) calculations (data not shown).

\section{Assumptions}

The GHG evaluated in this study in the context of crop production were $\mathrm{N}_{2} \mathrm{O}$ and $\mathrm{CH}_{4}$. Carbon dioxide emitted by livestock and $\mathrm{CO}_{2}$ from plant respiration were considered as part of the continuous biological process of carbon fixation, utilization, and respiration (Knapp et al., 2014), and therefore not included. Secondary emissions of transportation and machinery fuel combust, electricity, and plastic use were not included in this study because data for these calculations (i.e., fuel usage, electricity, transportation) were not available from the original survey.

Base land area required for crop production were calculated using 16-yr yield averages from WICST to project hectares of production used to supply the feed volumes reported by farms characteristic of the different clusters. This projection includes both land that was used by the dairy directly as well as land associated with production of purchased feed.

The pasture system on the WICST trial was not managed using certified organic production methods; however, the only external inputs used in this system (in addition to manure deposited by grazing cows) were minimal applications of synthetic fertilizer and spottreatment of noxious weeds with clopyralid herbicide. As per the IPCC (2006b) estimations, $1 \%$ of total $\mathrm{N}$ applied is lost as $\mathrm{N}_{2} \mathrm{O}$ emissions, regardless of the source of the N. Thus, assumptions were made that similar yields would be produced from an organically managed pasture, and that organic farmers would apply the equivalent amount of $\mathrm{N}$ as manure, with a similar proportion of $\mathrm{N}$ lost as $\mathrm{N}_{2} \mathrm{O}$.

Colmenero and Broderick (2006) found that replacing corn grain with soybean meal did not affect DMI, milk production, or diet digestibility when dietary CP level increased from 17.8 to $19.4 \%$, which was similar to the dietary CP range of our study. In addition, Sirohi et al. (2011) found that replacing raw soybean with roasted soybean had no effect on performance (DMI and milk production) in lactating crossbred cows. Therefore, DMI and milk production were assumed to be constant, regardless of the combination of CG and $\mathrm{SB}$ in the ration.

\section{RESULTS}

\section{Allocation to Milk and Meat}

Clusters 1, 3, and 4 had similar allocation factors to milk (0.82-0.85); however, cluster 2 had a lower allocation factor (0.71) as compared with the other 3 clusters (Table 1). Cluster 2 had low milk production and a greater proportion of first-lactation cows, both of which contribute to the low allocation factor to milk.

\section{Land Required and Associated Emissions}

Average annual DM yields (mean $\pm \mathrm{SD}$,) of crops were $8,530 \pm 1,941,22,838 \pm 5,194,2,772 \pm 757,11,057$ $\pm 1,353,9,399 \pm 1,150$, and $8,454 \pm 2,921 \mathrm{~kg}$ of DM/ ha for CG, corn silage, SB, alfalfa hay, alfalfa haylage, and pasture grass, respectively. As the proportion of CG decreased in the ration and the proportion of SB increased, total cropland needed to supply the concentrate feed increased for all 4 clusters (Table 4) due to the relatively lower yields of SB than CG.

On a per-cow basis, cluster 1 required the greatest land base for feed production, followed by clusters 3 , 4 , and 2. The land demand required for feed production, as determined by average crop yields from WICST and the amount of feed defined by the different feeding strategies, trended with the total DMI per cow per day of each cluster $(22.1,15.2,20.9$, and $18.1 \mathrm{~kg}$ of DM/cow per day, for clusters $1,2,3$, and 4 , respectively). Cluster 2 used the largest pasture areas and the least row cropland of the 4 cluster, due to its long grazing period and heavy reliance on pasture for feeding. Clusters 3 and 4 were moderate with respect to their land base needs for feed production, falling between the other 2 clusters. Milk production per hectare of land ( $\mathrm{kg}$ of ECM/ha of 
land) was highest in cluster 3 , followed by clusters 4 , 1 , and 2. Increasing SB proportion in concentrate decreased the milk production per hectare of land because of lower yield of SB, compared with CG (Table 4).

\section{Cropland and Pasture $\mathrm{N}_{2} \mathrm{O}$ Emissions}

The per-hectare emission from each type of cropland or pasture, including direct $\mathrm{N}_{2} \mathrm{O}$ emission from crop and cover crop residue, indirect $\mathrm{N}_{2} \mathrm{O}$ emissions from $\mathrm{N}$ leaching and $\mathrm{NH}_{3}$ volatilization, and $\Delta \mathrm{SC}$, are depicted in Table 5. Without accounting for $\Delta \mathrm{SC}$, the production of organic corn resulted in the greatest $\mathrm{N}_{2} \mathrm{O}$ emissions $\left(1,569 \mathrm{~kg}\right.$ of $\mathrm{CO}_{2}$ eq./ha), followed by the production of organic alfalfa hay, pasture, and SB. According to 20-yr of soil carbon data collected from WICST, all cropland and pasture data indicated a loss of soil carbon, with the magnitude of loss greater in row crops and less in perennial forage and pasture systems (Table 5).

Direct $\mathrm{N}_{2} \mathrm{O}$ from crop and cover crop residual was the major component of total $\mathrm{N}_{2} \mathrm{O}$ emission in alfalfa hay, $\mathrm{SB}$, and pasture. Estimated indirect $\mathrm{N}_{2} \mathrm{O}$ emissions resulting from leaching and volatilization were substantially lower for SB compared with other crop types and pasture, although still relatively low within the other 3 crop types (Table 5).

Total $\mathrm{N}_{2} \mathrm{O}$ emissions (average at $102 \mathrm{~kg}$ of $\mathrm{CO}_{2}$ eq./t of ECM) from cropland (including row crops and pasture), as depicted in Table 6, contributed to $8.0 \%$ of total GHG emission per kilogram of ECM (average at $1,297 \mathrm{~kg}$ of $\mathrm{CO}_{2}$ eq./t of ECM). Overall, the clusters with feeding strategies emphasizing more time on pasture (2 and 4) resulted in lower GHG emissions associated with cropland, both with and without accounting for $\Delta \mathrm{SC}$. Average $\mathrm{N}_{2} \mathrm{O}$ emission from cropland was 107, 102 , and $97 \mathrm{~kg}$ of $\mathrm{CO}_{2}$ eq./ $\mathrm{t}$ of $\mathrm{ECM}$ with the $\mathrm{AC}, \mathrm{BL}$, and $\mathrm{HC}$ scenarios, respectively. Without considering $\Delta \mathrm{SC}$ associated with the land required for feed production of each of the clusters, emissions decreased as the proportion of SB in the diet increased because of lower $\mathrm{N}$ fertilization requirements of $\mathrm{SB}$ as compared with CG.

When evaluated on a land emissions per metric tonne of ECM basis without accounting for $\Delta \mathrm{SC}$, cluster 2 had the greatest GHG emissions, followed by clusters 1, 4 , and 3. However, when accounting for $\Delta \mathrm{SC}$ associated with the various crop rotation and production strategies, these rankings changed. Cluster 1 had the greatest land GHG emission, followed by clusters 4, 3, and 2 .

\section{Methane Emission from Enteric Fermentation}

Enteric $\mathrm{CH}_{4}$ emission contributed $45.6 \%$ of total farm GHG emission without $\Delta \mathrm{SC}$. Cluster 2 resulted in the 
greatest enteric $\mathrm{CH}_{4}\left(\mathrm{~kg}\right.$ of $\mathrm{CO}_{2}$ eq./t of ECM) emission, followed by clusters 4,1 , and 3 . Average enteric $\mathrm{CH}_{4}$ emission was 593,592 , and $591 \mathrm{~kg}$ of $\mathrm{CO}_{2}$ eq./t of ECM with the AC, BL, and $\mathrm{HC}$ scenarios, respectively. Increasing the $\mathrm{SB}$ proportion in concentrate resulted in a limited reduction in the enteric $\mathrm{CH}_{4}$ emission per kilogram of ECM due to its higher fat content. Ranking among clusters remained the same under all 3 concentrate scenarios.

\section{Methane and $\mathrm{N}_{2} \mathrm{O}$ Emission from Manure Management}

Emissions (both $\mathrm{N}_{2} \mathrm{O}$ and $\mathrm{CH}_{4}$ ) from manure management contributed $26.3 \%$ to the farm total GHG emission without $\Delta$ SC. Emission of both GHG occurred during manure management processes. Nitrous oxide was primarily emitted as a result of direct manure deposition on the pasture and after manure applied on cropland, whereas $\mathrm{CH}_{4}$ emission associated with manure storage was much greater than deposited manure on pasture and manure land application (Table 6). Higher SB proportions in concentrate increased the dietary CP (Table 3) content and led to greater $\mathrm{N}$ content in manure, which eventually increased $\mathrm{N}_{2} \mathrm{O}$ emission during manure management. Higher SB proportion in concentrate also increased manure volatile solid content by increasing dietary GE content, which led to higher $\mathrm{CH}_{4}$ emissions during manure management.

Greenhouse gas emissions from manure deposited on pasture during grazing, including $\mathrm{N}_{2} \mathrm{O}$ and $\mathrm{CH}_{4}$ in kilograms of $\mathrm{CO}_{2}$ eq., are reported in Table 6 on an emission per metric tonne of ECM basis. Cluster 2 had the greatest GHG emission from manure deposited on pasture, followed by clusters 4,1 , and 3 . This ranking was the same as the grazing time on pasture (i.e., cluster 2 had the longest grazing time on pasture over a year, followed by clusters 4,1 , and 3 ; Table 1 ). Despite cluster 4 had higher allocation factor to milk than cluster 2 (0.84 vs. 0.71; Table 1$)$, greater ECM production in cluster 4 resulted in decreased GHG emission per metric tonne of ECM (5,495 vs. $3,857 \mathrm{~kg} /$ cow per year; Table 1).

\section{Manure Storage}

Emission from manure storage was greatest from cluster 1 , followed by clusters 2,4 , and 3 (Table 6 ).

\section{Manure Land Application}

Nitrous oxide was the dominant GHG resulting from manure applied to the cropland (Table 6). Total GHG emissions per metric tonne of ECM (for both milk and meat) after manure land application were greatest in cluster 2 and followed by cluster 1 . Cluster 3 was the lowest in $\mathrm{AC}$ and $\mathrm{BL}$, whereas cluster 4 was the lowest in $\mathrm{HC}$ (Table 6). Allocation factors changed the comparison between clusters. Cluster 1 had the highest GHG emission allocated to per metric tonne of ECM in $\mathrm{BL}$ and $\mathrm{HC}$, whereas cluster 2 had the highest GHG emission allocated to per metric tonne of ECM in AC. Cluster 3 had the lowest GHG emission allocated to per metric tonne of ECM in $\mathrm{BL}$ and $\mathrm{AC}$, whereas cluster 4 had the lowest GHG emission allocated per metric tonne of ECM in HC.

\section{Replacement Heifer Emission}

Replacement heifer GHG emission was $20.1 \%$ of total GHG emission per metric tonne of ECM without $\Delta$ SC. Cluster 2 had the highest replacement heifer emission, followed by clusters 1, 4, and 3. Replacement heifer emission per kilogram of ECM was highly related to percent of first-lactation cows and milk production.

\section{Farm-Level GHG Emission}

Farm-level GHG emission results were reported in Table 7. Farm-level GHG emission per metric tonne of ECM ranking was similar with and without considering $\Delta \mathrm{SC}$. The HC scenario had the greatest GHG emission per metric tonne of ECM and the value decreased as SB proportion in concentrate decreasing. Cluster 2 had the highest emission per metric tonne of ECM and cluster 3 the lowest emission per metric tonne of ECM under all 3 scenarios.

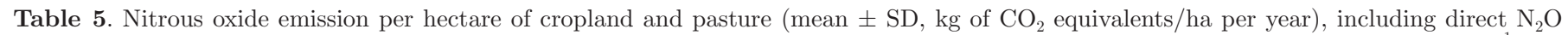
emission from crop and cover crop residue, indirect $\mathrm{N}_{2} \mathrm{O}$ emissions from $\mathrm{N}$ leaching and $\mathrm{NH}_{3}$ volatilization, and soil carbon change $(\Delta \mathrm{SC})^{1}$

\begin{tabular}{|c|c|c|c|c|}
\hline Item & Corn & Soybean & Hay & Pasture \\
\hline Direct $\mathrm{N}_{2} \mathrm{O}$ emission from crop and cover crop residue & $372 \pm 84$ & $135 \pm 37$ & $912 \pm 112$ & $297 \pm 102$ \\
\hline Direct $\mathrm{N}_{2} \mathrm{O}$ emissions from $\mathrm{N}$ applied as fertilizer and manure inputs & $782 \pm 120$ & 0 & 0 & $178 \pm 315$ \\
\hline Indirect $\mathrm{N}_{2} \mathrm{O}$ emissions from leaching and volatilization & $416 \pm 56$ & $30 \pm 8.3$ & $205 \pm 25$ & $249 \pm 137$ \\
\hline Total $\mathrm{N}_{2} \mathrm{O}$ emission per hectare of land without $\Delta \mathrm{SC}$ & $1,569 \pm 206$ & $165 \pm 45$ & $1,117 \pm 137$ & $723 \pm 543$ \\
\hline$\Delta \mathrm{SC}$ & $-2,310$ & $-2,347$ & $-2,310$ & -30 \\
\hline Total $\mathrm{N}_{2} \mathrm{O}$ emission per hectare of land with $\Delta \mathrm{SC}$ & $3,879 \pm 206$ & $2,512 \pm 45$ & $3,427 \pm 137$ & $753 \pm 543$ \\
\hline
\end{tabular}

${ }^{1}$ Negative values of $\Delta \mathrm{SC}$ indicate soil carbon loss. 
DAIRY INDUSTRY TODAY

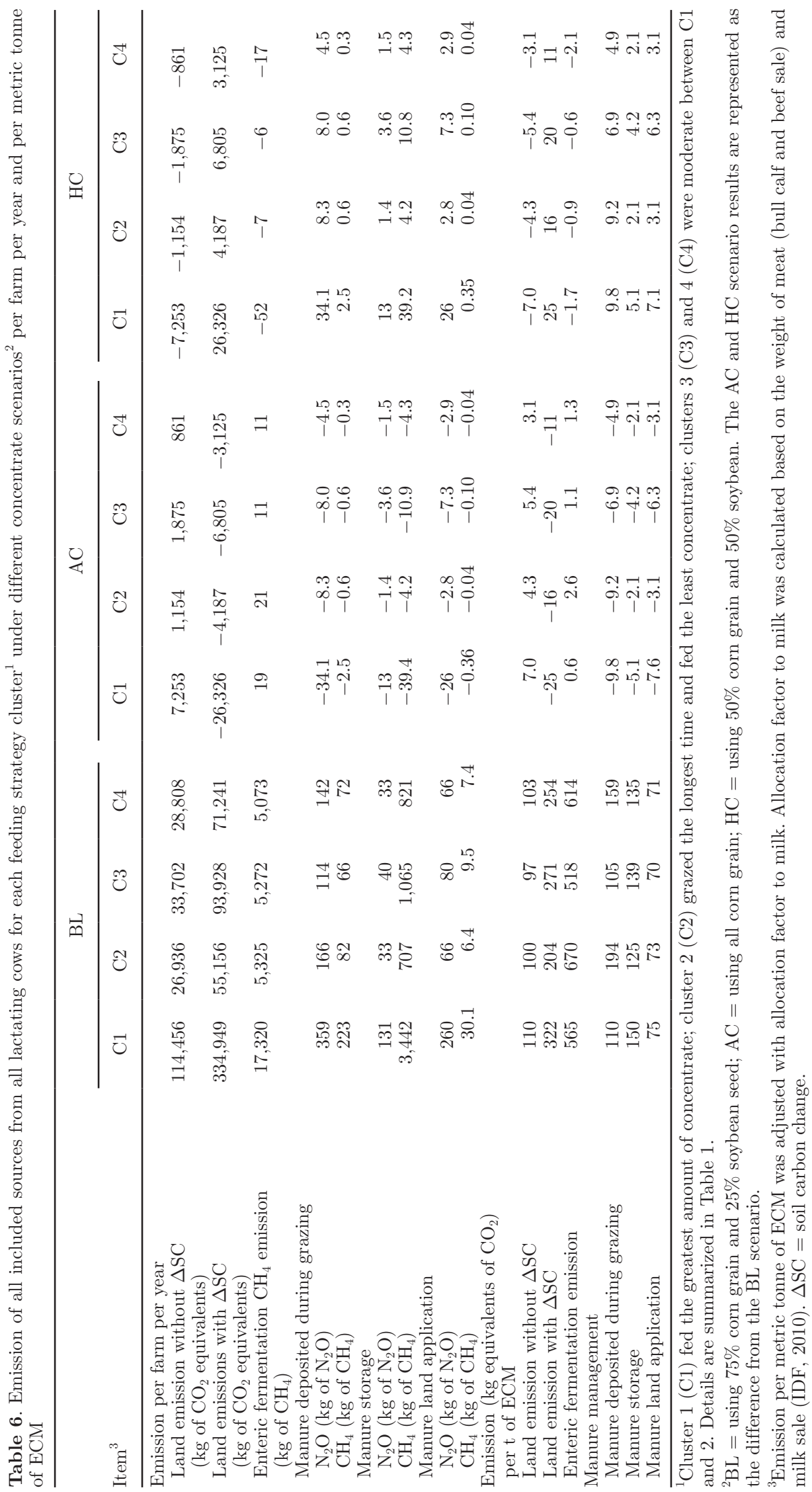


LIANG ET AL.

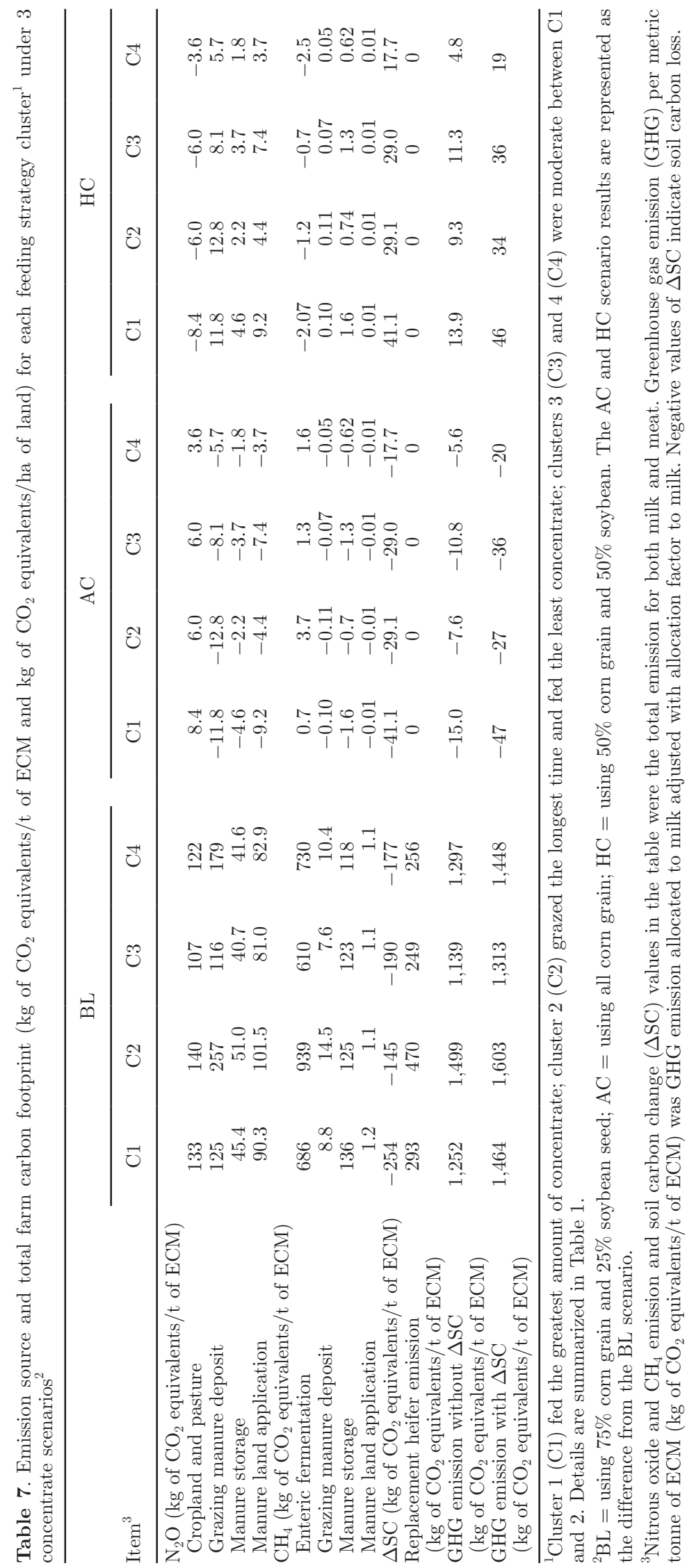




\section{DISCUSSION}

\section{Production System and Functional Unit}

The primary objective of our paper was to evaluate the effect of different herd feeding strategies to inform best strategies to reduce the GHG emission of Wisconsin dairy farms transitioning to organic production, using real-world values with respect to herd management, DMI, and crop production variables. Taking into account in-field emissions associated with crop production required to meet feed needs, as well as the GHG emissions resulting from herd enteric fermentation and manure production and management, our goal was to holistically assess the combined effect of feeding strategies and the associated manure and land use management on GHG emission. Although integrating both the crop and animal management effects on GHG emissions, we focused our assessment on calculations using per metric tonne of ECM as the functional unit in the dairy production system. Whereas emissions per metric tonne of ECM is the most widely used functional unit in dairy farm LCA (Thomassen and De Boer, 2005; Opio et al., 2013), the evaluation of emissions on a per-hectare of land and a per-cow basis may provide unique interpretations and insights into LCA for organic dairies. Expressing GHG emissions as per-hectare of land may more accurately reflect the effects of land use change and optimization of crop production approaches, thus affecting the creation of policies that promote the expansion of pasture-based feed strategies and related incentives with respect to carbon sequestration potential. Expressing results as per-cow can provide estimates of changes in emissions resulting from herd expansion, as well as provide comparisons of the relative emissions of herds with varying genetics. In the results described above, estimations of farm-level emissions (including row and pasture cropland, associated soil carbon change, enteric fermentation, and manure management) reflected several aspects of management and productivity, including herd size, feeding strategies, and herd productivity.

Although secondary emissions were not included in this assessment, they can contribute substantially to the farm-level GHG emission. Secondary emissions include emissions from concentrate production, fertilizer production, fuel combustion, and electricity (O'Brien et al., 2014). Thoma et al. (2013) estimated farm energy (both electricity and fuel on farm) contributed $4 \%$ to the carbon footprint of fluid milk in the United States across the entire supply chain and $12.8 \%$ of GHG emission on farm (feed and milk production). However, when considering secondary emissions on Wisconsin's organic dairy farms, several of these emission sources can be considered negligible. Emissions associated with fertilizer production are minimal within organic production systems due to prohibited use of synthetic nitrogen. Emissions associated with transportation of feed could be greater for organic farms than conventional farms, as organic feed may be less readily available in certain areas of the United States; however, the majority of organic dairy farms in Wisconsin produce enough feed within their own operation to meet their herd's requirements.

However, across organic management strategies for organic dairies, differences in secondary emissions may emerge due to different herd management approaches. Organic farms with longer grazing time may have lower energy usage than the organic farms with shorter grazing time due to less electricity in lighting, ventilation, and so on (Rotz et al., 2010). Farms that heavily relied on concentrate (i.e., cluster 1 and 3) may have higher secondary emission from concentrate production than farms that have greater intake from pasture (clusters 2 and 4). Despite these potential secondary emission difference between clusters, if secondary emissions were included in our analyses, cluster 3 would remain lowest with respect to GHG emission per metric tonne of ECM, and cluster 2 would remain the highest due to the magnitude of difference between clusters 3 and 2 $(31.6 \%)$. However, the inclusion of secondary emissions may change the comparison between cluster 4 and 1 , as the 2 clusters were more similar in GHG emissions per metric tonne of ECM.

Clusters 1, 3, and 4 had a close allocation factor as compared with the default value of 0.856 from IDF (2010). The low allocation factor to milk in cluster 2 reduced the difference of GHG emission allocation to per metric tonne of ECM among clusters. Although cluster 2 had the lowest milk production in all 4 clusters, the high percent of first-lactation cows and number of bull calves sold per year distributed a larger proportion of GHG emission to meat and decreased the allocation factor to milk.

\section{Soybean Proportion in Concentrate and GHG Emission}

Overall feeding strategies, as well as the SB proportion in the concentrate, influenced the land demand and associated field GHG emission, enteric $\mathrm{CH}_{4}$ emission, and manure GHG emission associated with farms in each cluster. As shown in Table 7, the GHG emission from in-field emissions and enteric fermentation decreased as the proportion of SB in the concentrate increased for all clusters, as expressed on a per-metric tonne of ECM basis. Decreased reliance on corn in the crop rotation resulted in decreased $\mathrm{N}$ fertilization 
required for crop production, further resulting in less $\mathrm{N}_{2} \mathrm{O}$ emissions as compared with strategies more reliant on the production of corn. These results (Table 5) are similar to results of Osterholz et al. (2014), in which direct measurements of $\mathrm{N}_{2} \mathrm{O}$ emissions were obtained from the WICST experiment. Greater SB proportion in the concentrate increased dietary ether extract content, which could reduce enteric $\mathrm{CH}_{4}$ emission by suppressing rumen methanogen population and reducing fiber digestibility (Table 3; Knapp et al., 2014). The higher dietary $\mathrm{CP}$ due to greater SB proportion in concentrate increased the $\mathrm{N}$ content in manure with same milk protein percent and greater GE value increased volatile solid value in manure.

\section{Feeding Strategies and Cropping Strategies}

We assumed that all the feed was produced under the typical organic cropping practices and pasture management that are represented in the WICST, either produced on-farm or as purchased feed (Table 5). Different phases of typical crop rotations in Wisconsin, including those in organic production systems, are associated with different degrees of $\mathrm{N}_{2} \mathrm{O}$ emissions and $\Delta$ SC (Sanford et al., 2012; Osterholz et al., 2014). Corn had the greatest $\mathrm{CO}_{2}$ eq. emission per hectare without $\Delta \mathrm{SC}$, followed by alfalfa hay, pasture, and SB. This ranking was primarily driven by the inputs required for the production for the associated crops, with $\mathrm{N}$ being delivered as organically approved amendments.

The effect of cropping system (row crop, hay, and pasture) associated with a feeding strategy on GHG emissions per hectare of land differed when $\Delta \mathrm{SC}$ were considered. Results from WICST trial failed to demonstrate the occurrence of soil organic carbon sequestration, indicating soil carbon loss was occurring in all crop production strategies, including grain-, forage-, and pasture-based systems (Table 5). However, whereas the magnitude of $\Delta \mathrm{SC}$ was similar (and marked) in the row crop and hay systems, $\Delta \mathrm{SC}$ was nearer to net zero in land used for pasture. Thus, pasture demonstrated lower total GHG emissions per hectare of land than other crop types. The WICST is unique in that it considers the longevity and the breadth of cropping system approaches, intended to mirror the agricultural landscape of the upper Midwest region of the United States. Many other long-term systems trials focus on row crops and do not include a pasture treatment. The nearest comparison, both with respect to location and approach, might be the long-term experiment at the Kellogg Biological Station at Michigan State University; that long-term experiment included a mown grassland treatment, but not a managed pasture specifically (Grandy and Robertson, 2007). Whereas such studies show more carbon sequestration potential in the mown grassland, trends are similar to what has been found at the WICST, with alfalfa and grassland treatments demonstrating higher soil carbon levels as compared with other annual row crop treatments.

More generally, research has demonstrated that perennial grasslands are often found to be net C sinks (Allard et al., 2007; Soussana et al., 2007; Peichl et al., 2011), and management intended to increase forage production increases soil carbon (Conant et al., 2001; Allard et al., 2007; Ammann et al., 2007). However, the degree to which pastures sequester carbon can vary; Skinner and Dell (2015) found that a high-fertility pasture that had been perennial grassland for more than $40 \mathrm{yr}$ was a significant net $\mathrm{CO}_{2}$ source, whereas a lowerfertility pasture that had been tilled and replanted more recently was neither a source nor a sink. Additionally, the degree to which land under various management strategies sequesters or loses carbon can decrease over time, as previously depleted stocks are replenished and soils return to equilibrium conditions where inputs and outputs are balanced (Smith, 2004).

\section{Grazing Practice and GHG Emission}

Previous studies have demonstrated that pastures can sequester carbon by building soil OM (Powlson et al., 2011; Stockmann et al., 2013; Machmuller et al., 2015). However, the data derived from the rich Mollisol soils of the WICST trial showed that, although pastures were closer to achieving zero net emissions, pastures do not necessarily sequester substantial amounts of soil carbon as measured in the 20-yr timeframe represented in the WICST (Sanford et al., 2012). Nevertheless, pasture-based systems were shown to lose less carbon than other crop-production strategies, which explained the low GHG emission from cluster 2 under BL and AC considering $\triangle \mathrm{SC}$.

When considering the effect of increased incorporation of pasture into an organic dairy feeding strategy on GHG emissions, our analysis, using real-world milk production values achieved by organic farms using these feeding models, illustrates several important points that must be considered when assessing the benefits of pasture-based production. First, from the data collected on working organic farms through the Hardie et al. (2014) survey, farms that were more heavily integrating pasture into feeding strategies tend to have lower overall milk productivity. This was particularly evident in cluster 2, which almost solely relied on DMI from pasture for herd's feed needs, to the point of employing a seasonal milking strategy with drying off periods during the off-pasture season (Table 1). Additionally, this difference further magnified when comparing clusters 3 


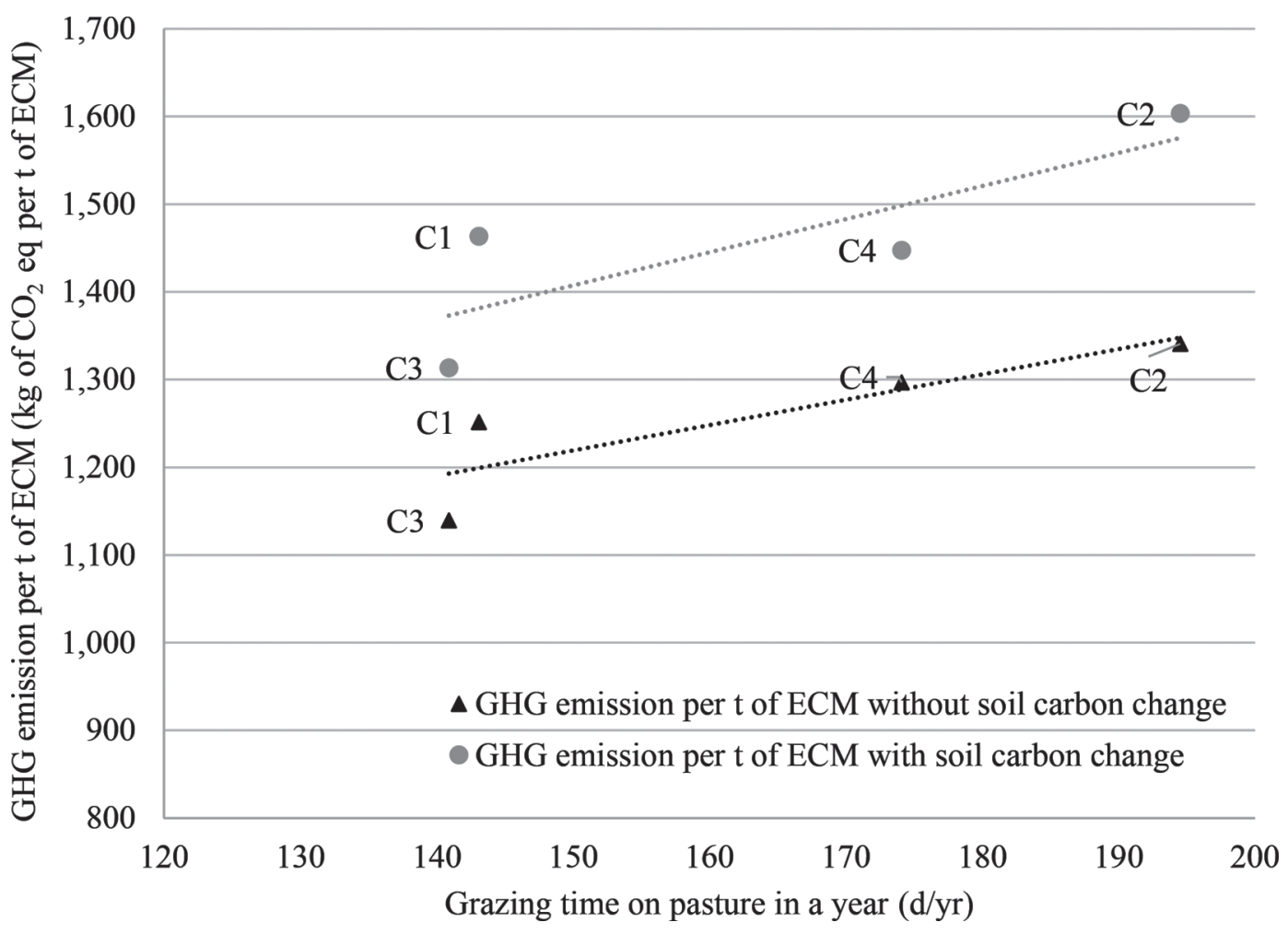

Figure 1. Relationship between grazing time on pasture (d/yr) and greenhouse gas (GHG) emission allocated to milk. Cluster 1 (C1) fed the greatest amount of concentrate; cluster 2 (C2) grazed the longest time and fed the least concentrate; clusters 3 (C3) and 4 (C4) were moderate between clusters 1 and $2 . \mathrm{CO}_{2}$ eq. $=\mathrm{CO}_{2}$ equivalents.

and 4; whereas both strategies significantly integrated pasture into the herd feeding strategy, as required by organic regulation, cluster 4 tended to integrate more herd time on pasture while still supplementing with the same quantity of feeds, with an observed decrease in milk production (Tables 1 and 2). More intensive grazing practices led to higher GHG emission per metric tonne of ECM (Table 6; Figure 1), as intensive grazing practices combined with low concentrate inputs were associated with a decrease in milk production.

In addition to emissions related to differences in cropping systems associated with feeding strategies, the high protein content of pasture grass (Appendix Table A1) increased diet CP during the grazing season, which resulted in higher $\mathrm{N}_{2} \mathrm{O}$ emission by increasing the amount of nitrogen deposited on pasture. Longer time on pasture resulted in greater forage intake, which increased enteric fermentation. The magnitude of difference between the clusters with respect to grazing deposits were much greater compared with manure storage and spreading associated emission.

Our results align with Basset-Mens et al. (2009) and O'Brien et al. (2016), which demonstrated the positive effect of increased milk production on decreasing GHG emissions per unit of milk. Compared with Wisconsin,
Ireland experiences a longer grazing season (248 and $198 \mathrm{~d}$ for Ireland and Wisconsin, respectively; O'Brien et al., 2016). However, average milk production $(3,764$ $\mathrm{kg}$ of milk/cow per year delivered in New Zealand, 5,181 $\mathrm{kg}$ of fat- and protein-corrected milk production per cow per year in Ireland, and 5,793 $\mathrm{kg}$ of $\mathrm{ECM} / \mathrm{cow}$ per year in Wisconsin; Basset-Mens et al., 2009; O'Brien et al., 2016) was lower in Ireland than Wisconsin, with similar values reported from New Zealand. Feed supplement (concentrate, corn silage, alfalfa hay, and alfalfa haylage) differed across the 3 regions, with amounts of concentrates fed $(1.1 \mathrm{~kg} /$ cow per day in New Zealand, $1.7 \mathrm{~kg} / \mathrm{cow}$ per day in Ireland, $5.5 \mathrm{~kg} /$ cow per day in Wisconsin) lower in New Zealand and Ireland as compared with Wisconsin, with higher DMI derived from pasture. In New Zealand and Ireland, dairy farms aim to maximize milk production from pasture through extending the grazing period and implementing seasonal calving before the start of the grazing season. However, among the Wisconsin organic dairy farms, only low-input organic farms (cluster 2) fully implemented seasonal calving.

Although similarities exist with results of studies conducted in other regions, differences between our results and those obtained from pasture-based and low-input 
farms in other countries may be reflective of the shorter length of the pasture season in Wisconsin's colder climate. With less time annually to maximize forage production, many Wisconsin organic farms (clusters 1, 3 , and 4) feed more feed supplement, which translates into higher milk production (Hardie et al., 2014). Only the lower-input Wisconsin organic dairies (cluster 2) had similar feed supplement inputs $(2 \mathrm{~kg} / \mathrm{cow}$ per day) compared with New Zealand and Irish farms; however, with a shorter grazing season, Wisconsin farms also experienced lower milk production. Different grazing seasonality, pasture availability and quality, feed prices, and milk prices may all influence farmer's decisions and choices of management strategies; thus, the GHG emissions associated with farms elected to employ pasturebased and low-input methods.

\section{GHG per Metric Tonne of ECM}

Results of our study agree with previous results demonstrating that GHG emissions are negatively correlated with milk production, with high production diluting the emission from maintenance (Figure 1), and that that high-producing herds had lower GHG emissions per kilogram of ECM (Liang and Cabrera, 2015). Higher milk production is associated with higher DMI, which may lead to higher land requirements and more enteric fermentation. However, when considering emission per metric tonne of ECM, the benefits of higher milk production outweigh the greater emissions from the field or the intestine. The calculations demonstrate greater GHG emissions from farms heavily reliant on pasture (cluster 2) on a per-metric tonne of ECM basis (Figure 1). Strategic supplementation of concentrate to lactating cows during the grazing season could overall lower emissions per kilogram of ECM by increasing production. More concentrate in the diets resulted in an increase in milk production. The implementation of improved pasture management or grazing practices (e.g., management-intensive rotational grazing.), including the maintenance of optimal carbohydrate and protein concentrations in the forage, are essential to maintain high pasture quality to optimize increase milk production, as more than $30 \%$ of DMI must be from pasture. Other methods to improve productivity include improving reproductive performance and health status, which indirectly reduce GHG emission per metric tonne of ECM.

\section{Organic Dairy Farm Considerations and Challenges}

Increasingly, pasture-based systems have been promoted as tools to reduce the carbon footprint of livestock production systems and are discussed in the development of policy decisions (Merrill et al., 2015). Whereas our study supports the benefit of pasture from a crop-production perspective, it also demonstrates that, within a broader system context, the assessment becomes more nuanced as GHG emissions generated from livestock management are integrated into the calculations, particularly when the related productivity is taken into account.

Whereas pasture can remain a strategy to lower overall GHG emissions from certain livestock production approaches, more holistic optimization of management must be achieved to ensure pasture quality, pasture productivity, and milk production that balances production, profit, and sustainability goals. On many organic dairy farms, pasture productivity may require further management improvements, with yields and DM production not reaching their potential; thus, some organic dairies may not derive the feed value potential of this crop land base, affecting milk production. Organic dairy farms with well-managed grazing practices and adequate levels of concentrate in diet can both increase farm profitability (Hardie et al., 2014) and reduce GHG emission per kilogram of milk.

Effects of different dairy breeds on farm production and GHG emissions were not strongly included in this project; however, breeds of cows in organic farms strongly influence milk production and BCS (Roesch et al., 2005). Hristov et al. (2013) also suggested a possible breed effect on GHG per kilogram of milk, as Holsteins may have lower feed efficiency and lower protein and fat content in milk than other dairy breeds raised on pasture. Organic dairy farms must emphasize health traits, longevity, and fertility in addition to milk production in their breeding programs (Hardarson, 2001). Cows on some organic dairy farms (such as cluster 2) may have a herd with lower genetic potential of milk production than on the other farms, although they may be better suited for the different health needs of cows raised on pasture.

Additionally, the assessment of GHG emissions becomes further complicated by other nonproduction variables faced by organic dairy farms that were not considered in our study. These considerations and challenges include achieving the standards outlined in the federal organic regulation, land suitability (both onfarm and locally) for the production of tillage-intensive annual crops, marketing strategies of organic products, overall feed source stability and security, and farm financials. Further research is also needed on the effect of grazing management and feeding strategies on nonGHG environmental performance, such as biodiversity, ammonia volatilization, and $\mathrm{N}$ leaching and $\mathrm{P}$ run-off in organic dairy farms. 


\section{CONCLUSIONS}

Growing organic demand by consumers may attract conventional farms to transition to organic certification. During transition, farmers must make critical management decisions to meet organic regulations while considering environmental and production performance. Two decisions foundational to organic dairy farm management, herd feeding strategies and grazing practices, influence on-farm GHG emissions not only due to emissions related to crop production, but by substantially changing the productivity of the herd. Managing more land as pasture, and deriving a greater proportion of the herd feed requirements from pasture, can increase the GHG emissions per metric tonne of ECM if pasture and feed management are not optimized to maintain milk production potential. Different combinations of corn grain and soybean in concentrate had a relatively minor effect on emissions per metric tonne of ECM. Future research is needed to simultaneously optimize crop and milk production, GHG emissions, and farm profitability on organic dairy farms.

\section{ACKNOWLEDGMENTS}

This project was supported by USDA Hatch project to V.E. Cabrera WIS01699.

\section{REFERENCES}

Aguerre, M. J., M. A. Wattiaux, J. M. Powell, G. A. Broderick, and C. Arndt. 2011. Effect of forage-to-concentrate ratio in dairy cow diets on emission of methane, carbon dioxide, and ammonia, lactation performance, and manure excretion. J. Dairy Sci. 94:30813093. https://doi.org/10.3168/jds.2010-4011.

Allard, V., J.-F. Soussana, R. Falcimagne, P. Berbigier, J. M. Bonnefond, E. Ceschia, P. D'hour, C. Hénault, P. Laville, C. Martin, and C. Pinarès-Patino. 2007. The role of grazing management for the net biome productivity and greenhouse gas budget $\left(\mathrm{CO}_{2}\right.$, $\left\{\mathrm{N}_{2} \mathrm{O}\right\}$ and $\left.\mathrm{CH}_{4}\right)$ of semi-natural grassland. Agric. Ecosyst. Environ. 121:47-58. https://doi.org/10.1016/j.agee.2006.12.004.

Ammann, C., C. R. Flechard, J. Leifeld, A. Neftel, and J. Fuhrer. 2007. The carbon budget of newly established temperate grassland depends on management intensity. Agric. Ecosyst. Environ. 121:5-20. https://doi.org/10.1016/j.agee.2006.12.002.

Basset-Mens, C., S. Ledgard, and M. Boyes. 2009. Eco-efficiency of intensification scenarios for milk production in New Zealand. Ecol. Econ. 68:1615-1625. https://doi.org/10.1016/j. ecolecon.2007.11.017.

Beauchemin, K. A., H. H. Janzen, S. M. Little, T. A. McAllister, and S. M. McGinn. 2010. Life cycle assessment of greenhouse gas emissions from beef production in western Canada: A case study. Agric. Syst. 103:371-379.

Beauchemin, K. A., M. Kreuzer, F. O'Mara, and T. A. Mcallister. 2008. Nutritional management for enteric methane abatement: A review. Aust. J. Exp. Agric. 48:21-27. https://doi.org/10.1071/ EA07199.

Bellamy, P. H., P. J. Loveland, R. I. Bradley, R. M. Lark, and G. J. D. Kirk. 2005. Carbon losses from all soils across England and Wales 1978-2003. Nature 437:245-248.

Cederberg, C., and B. Mattsson. 2000. Life cycle assessment of milk production-A comparison of conventional and organic farm- ing. J. Clean. Prod. 8:49-60. https://doi.org/10.1016/S09596526(99)00311-X.

Colmenero, J. J., and G. A. Broderick. 2006. Effect of dietary crude protein concentration on milk production and nitrogen utilization in lactating dairy cows. J. Dairy Sci. 89:1704-1712.

Conant, R. T., K. Paustian, and E. T. Elliott. 2001. Grassland management and conversion into grassland: Effects on soil carbon. Ecol. Appl. 11:343-355. https://doi.org/10.1890/10510761(2001)011[0343:GMACIG]2.0.CO;2.

EPA. 2014. Inventory of U.S. Greenhouse Gas Emissions and Sinks: 1990-2013. US Environmental Protection Agency (EPA), Washington, DC.

Grandy, A. S., and G. P. Robertson. 2007. Land-use intensity effects on soil organic carbon accumulation rates and mechanisms. Ecosystems (N. Y.) 10:59-74. https://doi.org/10.1007/s10021-0069010-y.

Hardarson, G. H. 2001. Is the modern high potential dairy cow suitable for organic farming conditions? Acta Vet. Scand. Suppl. 95:63-67. https://doi.org/10.1186/1751-0147-43-S1-S63.

Hardie, C. A. 2013. General management and feeding strategies on Wisconsin organic dairy farms. Master's thesis, Dairy Science Department, University of Wisconsin-Madison.

Hardie, C. A., M. Wattiaux, M. Dutreuil, R. Gildersleeve, N. S. Keuler, and V. E. Cabrera. 2014. Feeding strategies on certified organic dairy farms in Wisconsin and their effect on milk production and income over feed costs. J. Dairy Sci. 97:4612-4623. https://doi. org/10.3168/jds.2013-7763.

Hristov, A. N., T. Ott, J. Tricarico, A. Rotz, G. Waghorn, A. Adesogan, J. Dijkstra, F. Montes, J. Oh, and E. Kebreab. 2013. Special topics-Mitigation of methane and nitrous oxide emissions from animal operations: III. A review of animal management mitigation options. J. Anim. Sci. 91:5095-5113.

Intergovernamental Panel on Climate Change (IPCC). 2006a. Emissions from livestock and manure management. Chapter 10 in 2006 Guidelines for National Greenhouse Gas Inventories. IPCC, Geneva, Switzerland.

Intergovernmental Panel on Climate Change (IPCC). 2006b. $\mathrm{N}_{2} \mathrm{O}$ emissions from managed soils, and co2 emissions from lime and urea application. Chapter 10 in 2006 Guidelines for National Greenhouse Gas Inventories. IPCC, Geneva, Switzerland.

Intergovernmental Panel on Climate Change (IPCC). 2013. The Physical Science Basis. Working Group I Contribution to the Fifth Assessment Report of the Intergovernmental Panel on Climate Change. IPCC, Geneva, Switzerland

International Dairy Federation (IDF). 2010. A common carbon footprint approach for dairy. Bull. Int. Dairy Fed. IDF, Brussels, Belgium.

Johnson, K. A., and D. E. Johnson. 1995. Methane emissions from cattle. J. Anim. Sci. 73:2483-2492.

Knapp, J. R., G. L. Laur, P. A. Vadas, W. P. Weiss, and J. M. Tricarico. 2014. Invited review: Enteric methane in dairy cattle production: Quantifying the opportunities and impact of reducing emissions. J. Dairy Sci. 97:3231-3261. https://doi.org/10.3168/ jds.2013-7234.

Liang, D., and V. E. Cabrera. 2015. Optimizing productivity, herd structure, environmental performance, and profitability of dairy cattle herds. J. Dairy Sci. 98:2812-2823. http://dx.doi.org/ https://doi.org/10.3168/jds.2014-8856.

Machmuller, M. B., M. G. Kramer, T. K. Cyle, N. Hill, D. Hancock, and A. Thompson. 2015. Emerging land use practices rapidly increase soil organic matter. Nat. Commun. 6:6995.

McBride, W. D., and C. Greene. 2009. Characteristics, Costs, and Issues for Organic Dairy Farming, ERR-82, U.S. Department of Agriculture, Economic Research Service, Washington, DC.

Merrill, J., R. Brillinger, and L. Kemp. 2015. Blueprint for a California program on climate and agriculture. California Climate and Agriculture Network, Sebastopol, CA.

Milesi Delaye, L. A., A. B. Irizar, A. E. Andriulo, and B. Mary. 2013. Effect of continuous agriculture of grassland soils of the Argentine Rolling Pampa on soil organic carbon and nitrogen. Appl. Environ. Soil Sci. 2013:487865. https://doi.org/10.1155/2013/487865. 
Moraes, L. E., A. B. Strathe, J. G. Fadel, D. P. Casper, and E. Kebreab. 2014. Prediction of enteric methane emissions from cattle. Glob. Change Biol. 20:2140-2148. https://doi.org/10.1111/ gcb.12471.

Myhre, G., D. Shindell, F.-M. Bréon, W. Collins, J. Fuglestvedt, J. Huang, D. Koch, J.-F. Lamarque, D. Lee, B. Mendoza, T. Nakajima, A. Robock, G. Stephens, T. Takemura, H. Zhan, and H. Zhang. 2013. Anthropogenic and natural radiative forcing. Clim. Change 2:659-740. https://doi.org/10.1017/ CBO9781107415324.018.

NRC. 2001. Requirements of Dairy Cattle. 7th rev. ed. Natl. Acad. Sci., Washington, DC.

O'Brien, D., J. L. Capper, P. C. Garnsworthy, C. Grainger, and L. Shalloo. 2014. A case study of the carbon footprint of milk from high-performing confinement and grass-based dairy farms. J. Dairy Sci. 97:1835-1851.

O'Brien, D., A. Geoghegan, K. McNamara, and L. Shalloo. 2016. How can grass-based dairy farmers reduce the carbon footprint of milk? Anim. Prod. Sci. 56:495-500. https://doi.org/10.1071/AN15490.

Ogino, A., H. Orito, K. Shimada, and H. Hirooka. 2007. Evaluating environmental impacts of the Japanese beef cow-calf system by the life cycle assessment method. Anim. Sci. J. 78:424-432.

Opio, C., P. Gerber, A. Mottet, A. Falcucci, G. Tempio, M. MacLeod, T. Vellinga, B. Henderson, and H. Steinfeld. 2013. Greenhouse gas emissions from ruminant supply chains-A global life cycle assessment. Food and Agriculture Organization of the United Nations, Rome, Italy.

Osterholz, W. R., C. J. Kucharik, J. L. Hedtcke, and J. L. Posner 2014. Seasonal nitrous oxide and methane fluxes from grain- and forage-based production systems in Wisconsin, USA. J. Environ. Qual. 43:1833. https://doi.org/10.2134/jeq2014.02.0077.

Peichl, M., P. Leahy, and G. Kiely. 2011. Six-year stable annual uptake of carbon dioxide in intensively managed humid temperate grassland. Ecosystems (N. Y.) 14:112-126. https://doi.org/10.1007/ s10021-010-9398-2.

Pelletier, N., R. Pirog, and R. Rasmussen. 2010. Comparative life cycle environmental impacts of three beef production strategies in the upper Midwestern United States. Agric. Syst. 103:380-389.

Posner, J. L., J. O. Baldock, and J. L. Hedtcke. 2008. Organic and conventional production systems in the Wisconsin integrated cropping systems trials: I. Productivity 1990-2002. Agron. J. 100:253-260. http://dx.doi.org/https://doi.org/10.2134/agronj2007.0058.

Posner, J. L., M. D. Casler, and J. O. Baldock. 1995. The Wisconsin integrated cropping systems trial: Combining agroecology with production agronomy. Am. J. Altern. Agric. 10:98-107.

Powlson, D. S., A. P. Whitmore, and K. W. T. Goulding. 2011. Soil carbon sequestration to mitigate climate change: A critical reexamination to identify the true and the false. Eur. J. Soil Sci. 62:42-55. https://doi.org/10.1111/j.1365-2389.2010.01342.x.

Roesch, M., M. G. Doherr, and J. W. Blum. 2005. Performance of dairy cows on Swiss farms with organic and integrated production. J. Dairy Sci. 88:2462-2475. https://doi.org/10.3168/jds.S00220302(05)72924-6.

Rotz, C. A., M. S. Corson, D. S. Chianese, S. D. Hafner, and C. U. Coiner. 2013. The Integrated Farm System Model Manual. USDA Agricultural Research Service, Washington, DC.

Rotz, C. A., F. Montes, and D. S. Chianese. 2010. The carbon footprint of dairy production systems through partial life cycle assessment. J. Dairy Sci. 93:1266-1282. http://dx.doi.org/https://doi. org/10.3168/jds.2009-2162.
Sanford, G. R., J. L. Posner, R. D. Jackson, C. J. Kucharik, J. L. Hedtcke, and T.-L. Lin. 2012. Soil carbon lost from Mollisols of the north central U.S.A. with 20 years of agricultural best management practices. Agric. Ecosyst. Environ. 162:68-76. https://doi. org/10.1016/j.agee.2012.08.011.

Sirohi, S. K., T. K. Walli, and R. K. Mohanta. 2011. Comparative evaluation of raw and roasted soybean in lactating crossbred cows. Trop. Anim. Health Prod. 43:725-731.

Sjaunja, L. O., L. Baevre, L. Junkkarinen, and J. Pedersen. 1990. A Nordic proposal for an energy corrected milk (ECM) formula. Pages 156-157 in International Committee for Recording the Productivity of Milk Animals.

Skinner, R. H., and C. J. Dell. 2015. Comparing pasture C sequestration estimates from eddy covariance and soil cores. Agric. Ecosyst. Environ. 199:52-57. https://doi.org/10.1016/j.agee.2014.08.020.

Smith, P. 2004. Soils as carbon sinks: The global context. Soil Use Manage. 20:212-218. https://doi.org/10.1111/j.1475-2743.2004. tb00361.x.

Soussana, J. F., V. Allard, K. Pilegaard, P. Ambus, C. Amman, C. Campbell, E. Ceschia, J. Clifton-Brown, S. Czobel, R. Domingues, C. Flechard, J. Fuhrer, A. Hensen, L. Horvath, M. Jones, G. Kasper, C. Martin, Z. Nagy, A. Neftel, A. Raschi, S. Baronti, R. M. Rees, U. Skiba, P. Stefani, G. Manca, M. Sutton, Z. Tuba, and R. Valentini. 2007. Full accounting of the greenhouse gas $\left(\mathrm{CO}_{2}, \mathrm{~N}_{2} \mathrm{O}\right.$, $\mathrm{CH}_{4}$ ) budget of nine European grassland sites. Agric. Ecosyst. Environ. 121:121-134. https://doi.org/10.1016/j.agee.2006.12.022.

Stockmann, U., M. A. Adams, J. W. Crawford, D. J. Field, N. Henakaarchchi, M. Jenkins, B. Minasny, A. B. McBratney, V. de Remy de Courcelles, K. Singh, I. Wheeler, L. Abbott, D. A. Angers, J. Baldock, M. Bird, P. C. Brookes, C. Chenu, J. D. Jastrow, R. Lal, J. Lehmann, A. G. O'Donnell, W. J. Parton, D. Whitehead, and M. Zimmermann. 2013. The knowns, known unknowns and unknowns of sequestration of soil organic carbon. Agric. Ecosyst. Environ. 164:80-99. https://doi.org/10.1016/j.agee.2012.10.001.

Thoma, G., J. Popp, D. Nutter, D. Shonnard, R. Ulrich, M. Matlock, D. Soo, Z. Neiderman, N. Kemper, C. East, and F. Adom. 2013. Greenhouse gas emissions from milk production and consumption in the United States: A cradle-to-grave life cycle assessment circa 2008. Int. Dairy J. 31:S3-S14.

Thomassen, M. A., and I. J. M. De Boer. 2005. Evaluation of indicators to assess the environmental impact of dairy production systems. Agric. Ecosyst. Environ. 111:185-199. https://doi.org/10.1016/j. agee.2005.06.013.

USDA. 2013. Organic Livestock Requirements. National Organic Program, Agricultural Marketing Service, USDA, Washington, DC.

USDA Economic Research Service. 2013. Organic Market Overview. Accessed May 1, 2017. https://www.ers.usda.gov/topics/naturalresources-environment/organic-agriculture/organic-market-overview.aspx.

Wales, W., P. Doyle, and D. Dellow. 1998. Dry matter intake and nutrient selection by lactating cows grazing irrigated pastures at different pasture allowances in summer and autumn. Aust. J. Exp. Agric. 38:451-460.

Weiske, A., A. Vabitsch, J. E. E. Olesen, K. Schelde, J. Michel, R. Friedrich, and M. Kaltschmitt. 2006. Mitigation of greenhouse gas emissions in European conventional and organic dairy farming. Agric. Ecosyst. Environ. 112:221-232. https://doi.org/10.1016/j. agee.2005.08.023. 
Appendix

Table A1. Manure management of $\mathrm{CH}_{4}$ and $\mathrm{N}_{2} \mathrm{O}$ emission factors from IPCC (2006a,b), including manure deposited on pasture during grazing, liquid manure storage, and manure spread to the field

\begin{tabular}{|c|c|c|}
\hline Emission source & Prediction equation or emission factor ${ }^{1}$ & Unit \\
\hline Methane $\left(\mathrm{CH}_{4}\right)$ & $\begin{array}{l}-9.311+0.042 \times \mathrm{GE}+0.094 \times \mathrm{NDF}-0.381 \times \text { ether extract } \\
+0.008 \times \mathrm{BW}+1.621 \times \mathrm{MF}\end{array}$ & MJ/cow per day \\
\hline \multicolumn{3}{|l|}{ Deposited manure during grazing } \\
\hline Nitrous oxide $\left(\mathrm{N}_{2} \mathrm{O}\right)$ & $0.02 \times$ manure $\mathrm{N}$ deposited on pasture & $\mathrm{kg} / \mathrm{kg}$ of $\mathrm{N}$ \\
\hline Methane $\left(\mathrm{CH}_{4}\right)$ & $0.01 \times$ manure VS deposited on pasture $\times 0.67 \times \mathrm{B}_{0} \times 365$ & $\mathrm{~kg} / \mathrm{yr}$ \\
\hline \multicolumn{3}{|c|}{ 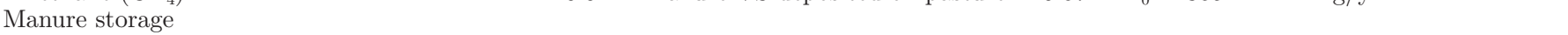 } \\
\hline \multicolumn{3}{|l|}{ Manure land application } \\
\hline Nitrous oxide $\left(\mathrm{N}_{2} \mathrm{O}\right)$ & $0.01 \times$ manure $\mathrm{N}$ spread & $\mathrm{kg} / \mathrm{kg}$ of $\mathrm{N}$ \\
\hline Methane $\left(\mathrm{CH}_{4}\right)$ & $0.001 \times$ manure VS spread $\times 0.67 \times \mathrm{B}_{0} \times 365$ & $\mathrm{~kg} / \mathrm{yr}$ \\
\hline Replacement heifer greenhouse gas emission & $11 \times \mathrm{BW} \times 0.92 \times$ percent of first-lactation cow $\times$ herd size & $\begin{array}{l}\mathrm{kg} \text { of } \mathrm{CO}_{2} \text { equivalents / } \\
\text { farm per year }\end{array}$ \\
\hline
\end{tabular}

$$
\begin{aligned}
& { }^{1} \mathrm{GE}=\text { gross energy, MJ } / \text { cow per day; } \mathrm{BW}, \mathrm{kg} / \mathrm{cow} ; \mathrm{MF}=\text { milk fat, } \% \\
& \mathrm{VS}=\text { volatile solid, } \mathrm{kg}=\left[\begin{array}{l}
\text { Gross energy intake, } \mathrm{MJ} / \mathrm{d} \times\left(1-\frac{\text { Feed digestibility, } \%}{100}\right)+ \\
(0.04 \times \text { Gross energy intake, } \mathrm{MJ} / \mathrm{d}) \times\left(\frac{100-\text { Ash, } \%}{18.45 \times 100}\right)
\end{array}\right] .
\end{aligned}
$$

Feed digestibility was set as $65 \%$ according to North America dairy cattle default digestibility value (Table 10A in IPCC, 2006a). $\mathrm{B}_{0}=$ the maximum methane-producing capacity, set as 0.24 according to North America dairy cattle default value (Table 10A in IPCC, 2006a).

Table A2. Average feed ingredient chemical composition ${ }^{1}$

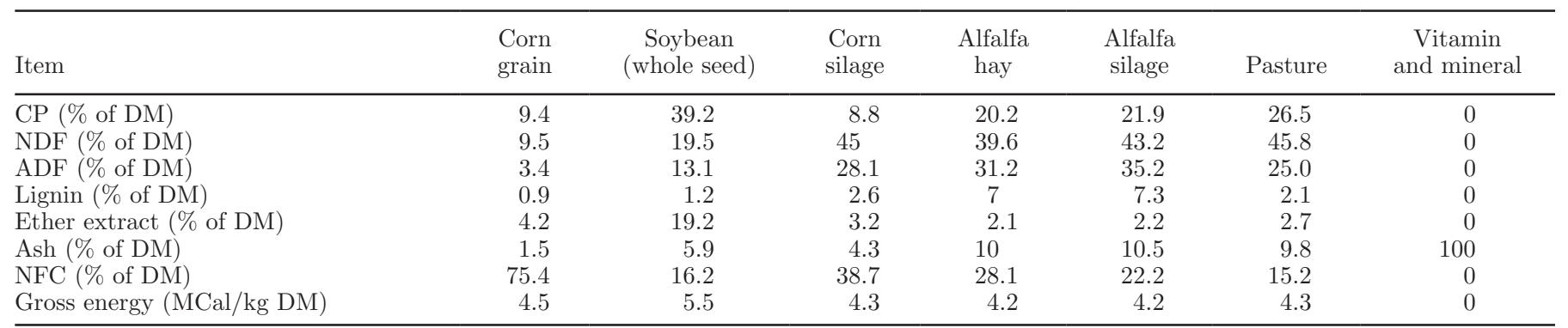

${ }^{1}$ Crude protein, NDF, ADF, ether extract, ash, and NFC values were calculated as the mean of book values from NRC (2001). Gross energy value calculated based on $\mathrm{CP}$, ether extract, and carbohydrate value in each ingredient as

Gross energy, Mcal $/ \mathrm{kg}$ of $\mathrm{DM}=\frac{(4.15 \times \text { carbohydrate, } \%+5.7 \times \mathrm{CP}, \%+9.4 \times \text { ethter extract, } \%)}{1,000} / 4.184$.

Carbohydrates $=100-$ ash, $\%-$ ether extract , $\%-$ CP, $\%$. 